Chapter 10

\title{
Obesity and Coronary Artery Disease
}

\author{
Ibrahim Akin, Uzair Ansari and \\ Christoph A. Nienaber \\ Additional information is available at the end of the chapter
}

http://dx.doi.org/10.5772/65977

\begin{abstract}
The impact of obesity can be better understood by studying the growing medical and socioeconomic burden of this often neglected public health epidemic. Traditionally associated with cardiovascular risk factors like hypertension, hyperlipidemia, and diabetes mellitus, morbid obesity has increasingly contributed to mortality among Western as well as Third World populations. Contemporary evidence has also consistently linked this patient cohort with a greater risk to develop coronary artery disease. Recent population-based registries indicate that 43 and $24 \%$ of all cases of coronary revascularization were performed in overweight and obese patients, respectively. In this context, although popular thought has reaffirmed the positive correlation between obesity and increased cardiovascular morbidity, some authors have opined a better clinical outcome in overweight and obese patients, a phenomenon they termed "obesity paradoxon." Conflicting data and the possibility of confounding bias have festered an ongoing debate challenging this "obesity paradox." In this review article, we present updated evidence and discuss the validity of the "obesity paradoxon" in a variety of clinical settings.
\end{abstract}

Keywords: coronary stent, obesity paradox, mortality, BMI

\section{Introduction}

Obesity has traditionally been defined as a body mass index (BMI) value $>30 \mathrm{~kg} / \mathrm{m}^{2}$, and its prevalence in the Western world, according to recent epidemiological data, could be as high as $36.5 \%$ [1]. Evidence of the growing prevalence of obesity can be inferred from the USA, where almost $70 \%$ of the population has been classified as obese; a significant increase from the $25 \%$ reported forty years ago [2]. The clinical relevance of obesity and its cluster of associated disorders, like arterial hypertension, dyslipidemia, diabetes mellitus, and sleep apnea syndrome, are demonstrated by its persistent link to an increased morbidity as well as 
mortality [3,4]. It is for this reason that initiatives detailing the primary and secondary prevention of cardiovascular disease in overweight and obese patients have laid specific emphasis on the significance of weight loss so as to modify cardiovascular risk [5-7]. Obese patients have an increased preponderance to develop atherosclerotic disease, especially coronary artery disease, which is characterized by a reduced sensitivity to insulin, enhanced free fatty acid turnover, increased basal sympathetic tone, a hyper-coagulable state, and finally with promotion of systemic inflammation [8, 9]. Population-based data suggest that 43 and $24 \%$ of all coronary revascularization in recent years were carried out in overweight and obese patients, respectively [10]. It has been speculated that the obese patient cohort is somehow associated with a clinical outcome far worse than that of a normal weight patient, and this theory is further substantiated by the existence of evidence describing the causative association of morbid obesity in cardiovascular disease. Interestingly, contemporary studies have recently elucidated the role of an "obesity paradoxon," describing the protective effect of obesity (when considering postoperative morbidity and mortality) in patients receiving either surgical or minimally invasive coronary revascularization [11]. This observation suggesting a better clinical outcome for obese patients is not only restricted to the clinical setting of coronary revascularization, as similar data have also been reported in cases of an acute myocardial infarction and heart failure $[12,13]$.

In this review article, we attempt to present an overview and summarize the evidence documented on "obesity paradoxon" in coronary artery disease.

\section{Stable coronary artery disease}

The correlation of BMI with clinical endpoints in the setting of interventional coronary revascularization from a single-center experience in patients $(n=3571)$ receiving balloon angioplasty was first reported in 1996 [14]. A detailed study of the in-hospital outcomes suggested higher rates of mortality $(2.8 \%$ vs. $0.9 \%$ vs. $3.7 \% ; p<0.001)$ in normal weight and obese patients as compared to overweight patients. This bias could also noted in the patients' need for blood transfusions $(11.9 \%$ vs. $7.4 \%$ vs. $8.4 \% ; p=0.003)$ and their corresponding rise in creatinine value $>1 \mathrm{mg} / \mathrm{dl}(3.6 \%$ vs. $1.8 \%$ vs. $1.8 \% ; p=0.018)$. Interestingly, the rates of myocardial infarction did not reflect any such patient group preference ( $3.5 \%$ vs. $3.4 \%$ vs. $4.7 \%$; $p=$ n.s.). The multicenter BARI registry evaluated the BMI of 3634 patients undergoing elective revascularization [2108 by interventional procedure (PCI) and 1526 by surgery (CABG)] at study entry between 1988 and 1991 [15]. Initial analyses of the results elicited a correlation between the body mass index and an increased risk of a major in-hospital event in the PCI arm. At the five-year follow-up interval, this correlation between BMI and mortality existed only in the CABG arm. The final results from the BARI registry suggested an inverse relationship between BMI and in-hospital outcome post-PCI without any major difference in long-term follow-up. Interestingly, although the study by Gruberg et al. [11] did indicate an inverse relationship in the 9633 patients evaluated between 1994 and 1999 at the 12-month follow-up for mortality (10.6\% vs. 5.7\% vs 4.9\%: 
$p<0.0001)$, rates of myocardial infarction ( $7.4 \%$ vs. $7.0 \%$ vs. $6.7 \%$ : $p=0.66)$ and target vessel revascularization $(20.2 \%$ vs. $22.0 \%$ vs. $22.4 \%$ : $p=0.16)$ did not vary significantly. Certain post-procedural clinical events like arterial hypertension, pulmonary congestion, impairment of renal function, bleeding events, access site complications, as well as those leading to mortality were seen more often in underweight patients as compared to the overweight and obese patient cohort.

The Scottish Coronary Revascularization Register offers another perspective to this debate. In contrast to previous all-comers trials, this study included only those patients ( $n=4880)$ undergoing elective PCI between 1997 and 2006, and without any known history of coronary artery disease. Patients evaluated to have a BMI in the range between 27 and $30 \mathrm{~kg} / \mathrm{m}^{2}$ were linked with lower all-cause mortality after 5 years of follow-up as compared to other weight groups. The introduction of a blanking time ( $<30$ days) to exclude periprocedural events as well as an adjustment to different baseline data did not impact the outcome of their study [16]. These conclusions were reaffirmed in the APPROACH registry, where a collective of 310,121 patients were treated conservatively $(n=7801)$, by PCI $(n=7017)$, or by CABG $(n=15,601)$ [17]. Lower mortality rates were recorded among overweight and obese patients as compared to normal weight patients in the cohort treated conservatively. These findings were also consistent for the CABG as well as the PCI group. An interesting corollary to these results centered around the use of baremetal stents (BMS) as well as a discussion on the meta-analysis of these single trials, suggesting an inverse relationship between BMI and the clinical outcome after stenting [18]. The results from studies of the balloon angioplasty and the BMS era are in stark contrast to other studies conducted in this timeframe, wherein patients receiving any of the two stents, DES or BMS, did not observe the "obesity paradoxon." An additional note in this context is summarized by the study of Poston et al. conducted in 1631 patients, suggesting that normal weight patients were older than obese or overweight patients at the time of hospital admission [18]. The 1-year follow-up mortality and risk for procedure revision were comparable in both groups.

In the TAXUS trials, of the 1307 patients stratified according to BMI and type of stent used (BMS versus DES) [20], higher rates of BMS in-stent restenoses were observed in obese and overweight patients than in normal-weight patients $(29.2 \%$ vs. $30.5 \%$ vs. $9.3 \%$; $p=0.01)$. The patients receiving DES had major cardiac event (MACE) rates skewing in favor of normal weight patients, and however, the clinical event rates in these different patient groups did not vary significantly. Subsequent results obtained from the German DES.DE registry would also validate these findings [21]. A total of 5806 patients assimilated from 98 sites in Germany were included in this registry for DES patients and followed up over a period of 12 months. The results would summarize suggestions made in previous trials, stating that the baseline comorbidity index was higher in obese patients as compared to overweight and normal weight patients, while the rates of in-hospital events were similar in all three groups. The follow-up after 1 year indicated no significant variability in mortality rates ( $3.3 \%$ vs. $2.4 \%$ vs. $2.4 \%$; $p=0.17)$, myocardial infarction $(2.8 \%$ vs. $2.3 \%$ vs. $2.3 \% ; p=0.45)$, target vessel revascularization $(10.9 \%$ vs. $11.7 \%$ vs. $11.6 \%$; $p=0.56)$, and major bleeding 


\begin{tabular}{|c|c|c|c|c|c|c|c|c|}
\hline Author & Year & $n$ & $\begin{array}{l}\text { Follow-up } \\
\text { (months) }\end{array}$ & Mortality & $\begin{array}{l}\text { Myocardial } \\
\text { infarction }\end{array}$ & $\begin{array}{l}\text { Target vessel } \\
\text { revascularization }\end{array}$ & $\begin{array}{l}\text { Renal } \\
\text { insufficiency }\end{array}$ & $\begin{array}{l}\text { Vascular } \\
\text { complications }\end{array}$ \\
\hline Ellis et al. [14] & 1996 & 3571 & 12 & + & - & - & + & + \\
\hline Gurm et al. [15] & 2002 & 3634 & 60 & + & n.a. & n.a. & n.a. & - \\
\hline Gruberg et al. [11] & 2002 & 9633 & 12 & + & - & - & + & - \\
\hline Poston et al. [19] & 2004 & 1631 & 12 & - & n.a. & - & n.a. & n.a. \\
\hline Nikolsky et al. [20] & 2005 & 1301 & 12 & - & - & - & n.a. & n.a. \\
\hline $\begin{array}{l}\text { Romero-Corral } \\
\text { et al. [18] }\end{array}$ & 2006 & $\begin{array}{l}250 \\
152\end{array}$ & 45 & + & n.a. & n.a. & n.a. & n.a. \\
\hline Oreopoulos et al. [17] & 2009 & $\begin{array}{l}31 \\
021\end{array}$ & 46 & + & n.a. & n.a. & n.a. & n.a. \\
\hline Hastie et al. [16] & 2010 & 4880 & 60 & + & n.a. & n.a. & n.a. & n.a. \\
\hline Akin et al. [21] & 2012 & 5806 & 12 & - & - & - & - & - \\
\hline
\end{tabular}

Table 1. Overview of literature addressing the "obesity paradox" in patients suffering from stable coronary artery disease undergoing coronary angiography and/or revascularization.

( $2.5 \%$ vs. $2.1 \%$ vs. $2.8 \% ; p=0.53)$ between normal weight, overweight, and obese patients, respectively (Table 1).

\section{Acute coronary syndrome}

The essential difference between stable coronary artery disease and an acute myocardial infarction is the existence of a pro-inflammatory state with different forms of hemodynamic, rhythmogenic, and hemostatic disturbance in the latter. Although the "obesity paradoxon" phenomenon has been evaluated in the patient population, there is lack of homogenous data establishing a potential link between BMI and clinical events in patients with acute myocardial infarction. Data analyses of the 6359 acute coronary syndrome (ACS) patients included in the PREMIER and TRIUMPH registries drawn to establish a relationship between BMI and survival rate yielded novel results [22]. BMI and mortality rates shared an inverse relationship $(9.2 \%$ vs. $6.1 \%$ vs. $4.7 \%$; $p<0.001$ ) irrespective of demographic age and sex distribution. The KAMIR registry yielded similar results in its 3824 ST-elevation myocardial infarction patient collective [23]. The baseline characteristics defined an older group of normal weight patients, with impairment of left ventricular ejection fraction and having a higher comorbidity index. The study eventually summarized that normal weight patients were associated with higher mortality rates.

An attempt to reaffirm this inverse relationship between BMI and clinical outcome in this scenario, however, was not possible in many other similarly conducted trials [24, 25]. Our research working group analyzed data from 890 patients diagnosed with ST-elevated myocardial infarction and followed them up for a duration of 12 months. This group also constituted patients diagnosed with cardiogenic shock. Interestingly, results indicated that clinical events did not vary significantly between all three weight groups, thus challenging the premise of the "obesity paradox" [26] (Table 2). 


\begin{tabular}{lllllllll}
\hline Author & Year & N & \multicolumn{3}{l}{$\begin{array}{l}\text { Follow-up } \\
\text { (months) }\end{array}$} & $\begin{array}{l}\text { Mortality Myocardial Target vessel } \\
\text { infarction }\end{array}$ & $\begin{array}{l}\text { Renal } \\
\text { revascularization insufficiency complications }\end{array}$ \\
\hline Kosuge et al. [25] & 2008 & 3076 & hospital & - & n.a. & n.a. & n.a. & n.a. \\
Kang et al. [23] & 2010 & 3824 & 12 & + & - & - & n.a. & n.a. \\
Camprubi et al. [24] & 2012 & 824 & hospital & - & n.a. & n.a. & n.a. & n.a. \\
Bucholz et al. [22] & 2012 & 6359 & 12 & + & n.a. & n.a. & n.a. & n.a. \\
Li et al. [27] & 2013 & 1429 & 12 & - & - & - & n.a. & n.a. \\
Shehab et al. [28] & 2014 & 4379 & 1 & - & - & - & n.a. & n.a. \\
Akin et al. [26] & 2015 & 890 & 12 & - & - & - & - & - \\
\hline
\end{tabular}

Table 2. Overview of literature addressing the "obesity paradox" in patients suffering from acute coronary syndrome, including cardiogenic shock, undergoing coronary revascularization.

\section{Rationale for the "obesity paradox"}

The growing incidence of obesity can be construed from data suggesting an increase of $37 \%$ from 13.6 to $18.6 \%$, in the cases of self-reported obesity, among men aged 35-49 since 1970 . Epidemiological factors attributed to the development of obesity and cardiovascular disease like arterial hypertension and diabetes mellitus are also on the rise [29, 30]. Recent efforts directed to reducing cholesterol levels and prevention of damaging smoking habits have helped sustain a decline in mortality from an acute coronary event. Frequent vessel revascularization has also possibly played a role in this positive development [31-33]. This, however, does not discount the influence of the metabolic syndrome and its link to various cardiovascular risk factors. Overweight and obese patients are derivatives of this syndrome, and the continual process of endothelial dysfunction and inflammation is often associated with the risk of developing atherosclerosis.

Evidence of this correlation constitutes an interesting paradox where better survival rates in an acute coronary event are real despite an increased incidence of obesity. This pertinent question has festered an ongoing debate as to the existence of the "obesity paradoxon" phenomenon in the spectrum of coronary artery disease [10-26].

An examination of current literature indicates that certain published data, essentially that comprising retrospective information, have claimed a U-shaped nonsignificant trend to suggest lower survival among underweight patients as compared to normal or mildly overweight patients. This, however, could be the result of a technical bias, which unfortunately cannot be fully corrected by statistical means.

A detailed analysis of these patient groups has suggested that up to $2 \%$ of patients who are underweight are likely to suffer from comorbid conditions, including malignancies, heart failure, malnutrition, and multi-organ dysfunction (MODS). This patient group also happens to constitute a significantly older age group demographic as compared to normal and obese patients [10,11,15], and clear evidence has linked elderly and frail patients to significantly poorer clinical outcomes regardless of management or reperfusion strategy [34, 35]. 
An interesting highlight in this respect is the influence of increasing age with its concomitant comorbidities on weight change [36-38]. The possibility of chronic disease leading to gradual weight loss had not been factored into presented trials. Another important confounding observation was the increased tendency of obese patients receiving diagnosis and treatment at an earlier stage in comparison with lean patients.

A recent survey of $>130,000$ patients suggested that patients with higher BMI adhere more sincerely to guidelines with regard to the use of standard drugs such as aspirin, beta-blockers, acetylcholinesterase inhibitors, angiotensin II receptor blockers, as well as lipid-lowering drugs and are increasingly likely to undergo invasive diagnostic and therapeutic interventions $[15,18,21]$. Additionally, overweight and obese subjects tended to be more stable at presentation, with the general constellation describing a patient lacking hemodynamic compromise, having a lower Killip class and also a preserved or less impaired ventricular function, which in turn proffers a better prognosis to the existing clinical scenario. These preliminary results present a clear challenge to the "obesity parodoxon" phenomenon.

Novel theories explaining the post-PCI "obesity paradoxon" hypothesize that obese patients have "larger vessels" somehow instituting a beneficial effect. A further consolidation of this hypothesis naturally suggests that post-PCI outcome is significantly worse in patients with smaller vessels $[39,40]$. The pharmacology of antithrombotic drugs is another interesting topic of discussion in this regard. The use of a standard dose rather than weightadjusted dosages precludes accurate measurement of the pharmacokinetic and pharmacodynamic effects of these medications in each patient. For example, the standard dose could very well be too high for an underweight patient (as calculated by BMI) resulting in significant bleeding events and is associated with a higher mortality rate [41]. Similarly, the sheath-to-artery size ratio varies in different BMI groups, and this could influence the rates of vascular complications [15]. These superficial differences observed in the context of a periprocedural event can reflect on the perceived improved survival noted among overweight patients [11, 42].

An absolute limiting factor in most studies centers around the use of BMI as a measure of obesity. The inadequate documentation of obesity distribution questions the plausibility of several results as this vital information has a significant impact in the clinical scenario. For example, central obesity has been associated with a poorer clinical outcome [43]. Other parameters such as waist circumference, waist-to-hip ratio, and weight change have not found mention in several of these trials [44-47]. Additionally, the inherent limitation of all these trials hypothesizing the "obesity paradoxon" is that they are an observational retrospective registry.

The failure to analyze potentially confounding variables such as physical inactivity, unintended weight loss, the influence of socioeconomic factors, as well as the short follow-up of these registries may have contributed to additional bias. Any existing relationship between obesity and in-hospital and short-term survival may have been lost, and the longer patients were followed. The possible buildup of the detrimental effects of obesity overtime could also have been studied in an extended follow-up period, perhaps establishing a link to increased late mortality $[48,49]$. 
The "obesity paradoxon" hypothesis hinges on certain questionable data. The proponents of this theory claim that replete adipose tissue plays the role of an endocrine organ [50] producing soluble tissue necrosis factor receptor and hence ensues the protective effect [51].

Conversely, higher levels of thrombotic factors as well as elevated plasminogen activator inhibitor-I in patients who are morbidly obese (BMI $\left.>40 \mathrm{Kg} / \mathrm{m}^{2}\right)$ probably contribute to the higher adjusted rates of post-PCI mortality seen in this patient group [52].

The suggestion, in early studies, that there exists an inverse relationship between underweight patients and outcomes in heart failure is what heralded the concept of "obesity paradoxon." However, an in-depth analysis of recently published data questions any such claim in the setting of coronary artery disease and modern coronary intervention. In fact, there is insufficient evidence or even proof of concept to veer away from the classic relationship between risk factors, confounding variables and prognostic outcomes. These association studies are limited not only by the lack of pathophysiological underpinnings, but also hindered by the use of descriptive notions and confounding variables with unknown impact to substantiate their results. While analyzing the neutralizing results of the German DES.DE Registry [21], the perception of obesity demonstrating a protective effect on outcomes post-PCI is seriously held in doubt and the provocative construct of an "obesity paradoxon" debased, as this hypothesis was never really substantiated in the clinical setting of coronary artery disease and PCI.

Finally, the support expressed by associative studies (in light of little or no statistical and biological evidence) leading to the hypothesis of an "obesity paradox" has been effectively debunked by the interpretation of recent clinical data. A contrarian concept would only hold traction if supported by plausible pathophysiology. In the context of coronary artery disease and PCI, there are hardly any convincing explanation and certainly no clinical data to justify an "obesity paradoxon."

Conflict of interest

No conflict of interest for all authors.

\section{Author details}

Ibrahim Akin ${ }^{1, *}$, Uzair Ansari ${ }^{1}$ and Christoph A. Nienaber ${ }^{2}$

*Address all correspondence to: ibrahim.akin@umm.de

1 University Mannheim, Mannheim, Germany

2 Royal Brompton Hospital and Harefield Trust, London, UK

\section{References}

[1] Berghöfer A, Pischon T, Reinhold T, Apovian CM, Sharma AM, Willich SN. Obesity prevalence from a European perspective: a systematic review. BMC Public Health 2008; 8: 200. [PMID:18533989 doi:10.1186/1471-2458-8-200] 
[2] Ogden CL, Carroll MD, Curtin LR, McDowell MA, Tabak CJ, Flegal KM. Prevalence of overweight and obesity in the United States, 1999-2004. JAMA 2006; 295: 1549-1555. [PMID:16595758 doi:10.1001/jama.295.13.1549]

[3] Garrison RJ, Higgins MW, Kannel WB. Obesity and coronary heart disease. Curr Opin Lipidol 1996; 4: 199-202. [PMID:8883494]

[4] Lakka HM, Laaksonen DE, Lakka TA, et al. The metabolic syndrome and total and cardiovascular disease mortality in middle-aged men. JAMA 2002; 288: 2709-2716. [PMID:12460094 doi:10.1001/jama.288.21.2709]

[5] Smith SC Jr, Blair SN, Bonow RO, Brass LM, Cerqueira MD, Dracup K, Fuster V, Gotto A, Grundy SM, Miller NH, Jacobs A, Jones D, Krauss RM, Mosca L, Ockene I, Pasternak RC, Pearson T, Pfeffer MA, Starke RD, Taubert KA. AHA/ACC guidelines for preventing heart attack and death in patients with atherosclerotic Cardiovascular Disease: 2001 update-a statement for healthcare professionals from the American Association and the American College of Cardiology. J Am Coll Cardiol 2001; 38: 1581-1583. [PMID:11691544 doi:10.1016/S0735-1097(01)01682-5]

[6] De Backer G, Ambrosioni E, Borch-Johnsen K, Brotons C, Cifkova R, Dallongeville J, Ebrahim S, Faergeman O, Graham I, Mancia G, Cats VM, Orth-Gomér K, Perk J, Pyörälä K, Rodicio JL, Sans S, Sansoy V, Sechtem U, Silber S, Thomsen T, Wood D; European Society of Cardiology Committee for Practice Guidelines. European guidelines on cardiovascular disease prevention in clinical practice: third joint task force of Eurpean and other societies on cardiovascular disease prevention in clinical practice (constituted by representatives of eight societies and by invited experts). Eur J Cardiovasc Prev Rehab 2003; 10: S1-S10. [PMID:1455889 doi:10.1097/01.hjr.0000087913.96265.e2]

[7] Willett WC, Dietz WH, Colditz GA. Guidelines for health weight. N Engl J Med 1999; 341: 427-434. [PMID:10432328 doi:10.1056/NEJM199908053410607]

[8] Hubert HB, Feinleib M, McNamara PM, Castelli WP. Obesity as an independent risk factor for cardiovascular disease: a 26-year follow-up of participiants in the Framingham Heart Study. Circulation 1983; 67: 968-977. [PMID:6219830 doi:10.1161/01.CIR.67.5.968]

[9] Whitlock G, Lewington S, Sherliker P, Clarke R, Emberson J, Halsey J, Qizilbash N, Collins R, Peto R. Body-mass index and cause-specific mortality in 900,000 adults: collaborative analyses of 57 prospective studies. Lancet 2009; 373: 1083-1096. [PMID:19299006 doi:10.1016/S0140-6736(09)60318-4]

[10] Minutello RM, Chou ET, Hong MK, Bergman G, Parikh M, Iacovone F, Wong SC. Impact of body mass index on in-hospital outcomes following percutaneous coronary intervention (report from the New York State Angioplasty Registry). Am J Cardiol 2004; 93: 1229-1232. [PMID:15135694 doi:10.1016/j.amjcard.2004.01.065]

[11] Gruberg L, Weissman NJ, Waksman R, Fuchs S, Deible R, Pinnow EE, Ahmed LM, Kent KM, Pichard AD, Suddath WO, Satler LF, Lindsay J Jr. The impact of obesity 
on the short-term and long-term outcomes after percutaneous coronary intervention: the obesity paradox? J Am Coll Cardiol 2002; 39: 578-584. [PMID:11849854 doi:10.1016/ S0735-1097(01)01802-2]

[12] Califf RM, Pieper KS, Lee KL, Van De Werf F, Simes RJ, Armstrong PW, Topol EJ. Prediction of 1-year survival after thrombolysis for acute myocardial infarction in the global utilization of streptokinase and TPA for occluded coronary arteries trial. Circulation 2000; 101: 2231-2238. [PMID:10811588 doi:10.1161/01.CIR.101.19.2231]

[13] Fonarow GC, Srikanthan P, Costanzo MR, Cintron GB, Lopatin M; ADHERE Scientific Advisory Committee and Investigators. An obesity paradox in acute heart failure: analysis of body mass index and in hospital mortality for 108,927 patients in the Acute Decompensated Heart Failure National Registry. Am Heart J 2007; 153: 74-81. [PMID:17174642 doi:10.1016/j.ahj.2006.09.007]

[14] Ellis SG, Elliott J, Horrigan M, Raymond RE, Howell G. Low-normal or excessive body mass index: newly identified and powerful risk factors for death and other complications with percutaneous coronary intervention. Am J Cardiol 1996; 78: 642-646. [PMID:8831397 doi:10.1016/S0002-9149(96)00386-4]

[15] Gurm HS, Whitlow PL, Kip KE, et al. The impact of body mass index on short- and long-term outcomes in patients undergoing coronary revascularization. Insight from the Bypass Angioplasty Revascularization Investigations (BARI). J Am Coll Cardiol 2002; 39: 834-840. [PMID:11869849 doi:10.1016/S0735-1097(02)01687-X]

[16] Hastie CE, Padmanabhan S, Slack R, Pell AC, Oldroyd KG, Flapan AD, Jennings KP, Irving J, Eteiba H, Dominiczak AF, Pell JP. Obesity paradox in a cohort of 4880 consecutive patients undergoing percutaneous coronary intervention. Eur Heart J 2010; 31: 222-226. [PMID:19687163 doi:10.1093/eurheartj/ehp317]

[17] Oreopoulos A, Mc Allister FA, Kalantar-Zadeh K, Padwal R, Ezekowitz JA, Sharma AM, Kovesdy CP, Fonarow GC, Norris CM. The relationship between body mass index, treatment, and mortality in patients with established coronary artery disease: a report from APPROACH. Eur Heart J 2009; 30: 2584-2592. [PMID:19617221 doi:10.1093/eurheartj/ ehp288]

[18] Romero-Corral A, Montori VM, Somers VK, Korinek J, Thomas RJ, Allison TG, Mookadam F, Lopez-Jimenez F. Association of bodyweight with total mortality and with cardiovascular events in coronary artery disease: a systematic review of cohort studies. Lancet 2006; 368: 666-678. [PMID:16920472 doi:10.1016/S0140-6736(06)69251-9]

[19] Poston WS, Haddock CK, Conard M, Spertus JA. Impact of obesity on disease-specific health status after percutaneous coronary intervention in coronary disease patients. Int J Obes Relat Metab Disord 2004; 28: 1011-1017. [PMID:15211370 doi:10.1038/sj.ijo.0802703]

[20] Nikolsky E, Kosinski E, Mishkel GJ, Kimmelstiel C, McGarry TF Jr, Mehran R, Leon MB, Russell ME, Ellis SG, Stone GW. Impact of obesity on revascularization and restenosis 
rates after bare-metal and drug-eluting stent implantation (from the TAXUS-IV trial). Am J Cardiol 2005; 95: 709-715. [PMID:15757595 doi:10.1016/j.amjcard.2004.11.020]

[21] Akin I, Tölg R, Hochadel M, Khattab AA, Schneider S, Senges J, Kuck KH, Richardt G, Nienaber CA; DES.DE (German Drug-Eluting Stent) Study Group. No evidence of "obesity paradox" after treatment with drug-eluting stents in a routine clinical practice: results from the prospective multicenter German DES.DE (German Drug-Eluting Stent) registry. JACC Cardiovasc Interv 2012; 5: 162-169. [PMID:22361600 doi:10.1016/j. jcin.2011.09.021]

[22] Bucholz EM, Rathore SS, Reid KJ, Jones PG, Chan PS, Rich MW, Spertus JA, Krumholz HM. Body mass index and mortality in acute myocardial infarction patients. Am J Med 2012; 125: 796-803. [PMID:22483510 doi:10.1016/j.amjmed.2012.01.018]

[23] Kang WY, Jeong MH, Ahn YK, Kim JH, Chae SC, Kim YJ, Hur SH, Seong IW, Hong TJ, Choi DH, Cho MC, Kim CJ, Seung KB, Chung WS, Jang YS, Rha SW, Bae JH, Cho JG, Park SJ; Korea Acute Myocardial Infarction Registry Investigators. Obesity paradox in Korean patients undergoing primary percutaneous coronary intervention in ST-segment elevation myocardial infarction. J Cardiol 2010; 55: 84-91. [PMID:20122553 doi:10.1016/j. jjcc.2009.10.004]

[24] Camprubi M, Cabrera S, Sans J, et al. Body mass index and hospital mortality in patients with acute coronary syndrome receiving care in a university hospital. J Obes 2012;2012:287939. [PMID:22900151 doi:10.1155/2012/287939]

[25] Kosuge M, Kimura K, Kojima S, Sakamoto T, Ishihara M, Asada Y, Tei C, Miyazaki S, Sonoda M, Tsuchihashi K, Yamagishi M, Shirai M, Hiraoka H, Honda T, Ogata Y, Ogawa H; Japanese Acute Coronary Syndrome Study (JACSS) Investigators. Impact of body mass index on in-hospital outcomes after percutaneous coronary intervention for ST segment elevation acute myocardial infarction. Circ J 2008; 72: 521-525. [PMID:18362419 doi:JST.JSTAGE/circj/72.521]

[26] Akin I, Schneider H, Nienaber CA, Jung W, Lübke M, Rillig A, Ansari U, Wunderlich N, Birkemeyer R. Lack of "obesity paradox" in patients presenting with ST-segment elevation myocardial infarction including cardiogenic shock-a multicenter German network registry analysis. BMC Cardiovasc Disord 2015; 15: 67. [PMID: 26162888 doi:10.1186/ s12872-015-0065-6]

[27] Li Y, Wu C, Sun Y, Jiang D, Zhang B, Ren L, Gao Y, Yu H, Yang G, Guan Q, Tian W, Zhang H, Guo L, Qi G. Obesity paradox: clinical benefits not observed in obese patients with ST-segment elevation myocardial infarction: a multivcenter, prospective, cohort study of the northern region of China. Int J Cardiol 2013; 168: 2949-2950. [PMID:23642605 doi:10.1016/j.ijcard.2013.03.169]

[28] Shehab A, Al-Dabbagh B, AlHabib K, Alsheikh-Ali A, Almahmeed W, Sulaiman K, Al-Motarreb A, Suwaidi JA, Hersi A, AlFaleh H, Asaad N, AlSaif S, Amin H, Alanbaei M, Nagelkerke N, Abdulle A. The obesity paradox in patients with acute coronary syndrome: 
results from the Gulf RACE-2 study. Angiology 2014; 65: 585-589. [PMID:23921507 doi:10.1177/0003319713497087]

[29] Ford ES, Capewell S. Coronary heart disease mortality among young adults in the U.S. from 1980 through 2002: concealed leveling of mortality rates. J Am Coll Cardiol 2007; 50: 2128-2132. [PMID:18036449 doi:10.1016/j.jacc.2007.05.056]

[30] O'Flaherty M, Ford E, Allender S, Scarborough P, Capewell S. Coronary heart disease trends in England and Wales from 1984 to 2004: concealed levelling of mortality rates among young adults. Heart 2007; 94: 178-181. [PMID: 17641070 doi:10.1136/ hrt.2007.118323]

[31] Unal B, Critchley JA, Capewell S. Explaining the decline in coronary heart disease mortality in England and Wales between 1981 and 2000. Circulation 2004; 109: 1101-1107. [PMID:14993137 doi:10.1161/01.CIR.0000118498.35499.B2]

[32] Ford ES, Ajani UA, Croft JB, Critchley JA, Labarthe DR, Kottke TE, Giles WH, Capewell S. Explaining the decrease in US deaths from coronary disease, 1980-2000. N Engl J Med 2007; 356: 2388-2398. [PMID:17554120 doi:10.1056/NEJMsa053935]

[33] Gregg EW, Cheng YJ, Cadwell BL, Imperatore G, Williams DE, Flegal KM, Narayan $\mathrm{KM}$, Williamson DF. Secular trends in cardiovascular disease risk factors according to body mass index in US adults. JAMA 2005; 293: 1868-1874. [PMID:15840861 doi:10.1001/ jama.293.15.1868]

[34] Holmes DR Jr, White HD, Pieper KS, Ellis SG, Califf RM, Topol EJ. Effect of age on outcome with primary angioplasty versus thrombolysis. J Am Coll Cardiol 1999; 33: 412-419. [PMID:9973021 doi:10.1016/S0735-1097(98)00579-8]

[35] Halkin A, Singh M, Nikolsky E, Grines CL, Tcheng JE, Garcia E, Cox DA, Turco M, Stuckey TD, Na Y, Lansky AJ, Gersh BJ, O'Neill WW, Mehran R, Stone GW. Prediction of mortality after primary percutaneous coronary intervention for acute myocardial infarction. The CADILLAC risk score. J Am Coll Cardiol 2005; 45: 1397-1405. [PMID:15862409 doi:10.1016/j.jacc.2005.01.041]

[36] Strandberg TE, Strandberg AY, Salomaa VV, Pitkälä KH, Tilvis RS, Sirola J, Miettinen TA. Explaining the obesity paradox: cardiovascular risk, weight change, and mortality during long-term follow-up in men. Eur Heart J 2009; 30: 1720-1727. [PMID:19429917 doi:10.1093/eurheartj/ehp162]

[37] Calle EE, Thun MJ, Petrelli JM, Rodriguez C, Heatzh CW Jr. Body-mass index and mortality in a prospective cohort of U.S. adults. N Engl J Med 1999; 341: 1097-1105. [PMID:10511607 doi:10.1056/NEJM199910073411501]

[38] O'Donovan G, Owen A, Kearney EM, Jones DW, Nevill AM, Woolf-May K, Bird SR. Cardiovascular disease risk factors in habitual exercisers, lean sedentary men and abdominal obese sedentary men. Int J Obes (Lond) 2005; 29: 1063-1069. [PMID:15925958 doi:10.1038/sj.ijo.0803004] 
[39] Schunkert H, Harrell L, Palacios IF. Implications of small reference vessel diameter in patients undergoing percutaneous coronary revascularization. J Am Coll Cardiol 1999; 34: 40-48. [PMID:10399990 doi:10.1016/S0735-1097(99)00181-3]

[40] Foley DP, Melkert R, Serruys PW. Influence of coronary vessel size on renarrowing process and late angiographic outcome after successful balloon angioplasty. Circulation 1994; 90: 1239-1251. [PMID:8087933 doi:10.1161/01.CIR.90.3.1239]

[41] Powell BD, Lennon RJ, Lerman A, Bell MR, Berger PB, Higano ST, Holmes DR Jr, Rihal CS. Association of body mass index with outcome after percutaneous coronary inetrvention. Am J Cardiol 2003; 91: 472-476. [PMID:12586271 doi:10.1016/S0002-9149(02)03252-6]

[42] Manson JE, Stampfer MJ, Henneckens CH, Williett WC. Body weight and longevity: a reassessment. JAMA 1987; 257: 353-358. [PMID:3795418 doi:10.1001/ jama.1987.03390030083026]

[43] Folsom AR, Kushi LH, Anderson KE, Mink PJ, Olson JE, Hong CP, Sellers TA, Lazovich D, Prineas RJ. Association of general and abdominal obesity with multiple health outcomes in older women: the Iowa Women's Health study. Arch Intern Med 2000; 160: 2117-2128. [PMID:10904454 doi:10.1001/archinte.160.14.2117]

[44] Yusuf S, Hawken S, Ounpunn S, Bautista L, Franzosi MG, Commerford P, Lang CC, Rumboldt Z, Onen CL, Lisheng L, Tanomsup S, Wangai P Jr, Razak F, Sharma AM, Anand SS; INTERHEART Study Investigators. Obesity and the risk of myocardial infarction in 27,000 participants from 52 countries: a case-control study. Lancet 2005; 366: 1640-1649. [PMID:16271645 doi:10.1016/S0140-6736(05)67663-5]

[45] Dagenais GR, Yi Q, Mann JF, Bosch J, Pogue J, Yusuf S. Prognostic impact of body weight and abdominal obesity in women and men with cardiovascular disease. Am Heart J 2005; 149: 54-60. [PMID:15660034 doi:10.1016/j.ahj.2004.07.009]

[46] Pischon T, Boeing H, Hoffmann K, Bergmann M, Schulze MB, Overvad K, van der Schouw YT, Spencer E, Moons KG, Tjønneland A, Halkjaer J, Jensen MK, Stegger J, Clavel-Chapelon F, Boutron-Ruault MC, Chajes V, Linseisen J, Kaaks R, Trichopoulou A, Trichopoulos D, Bamia C, Sieri S, Palli D, Tumino R, Vineis P, Panico S, Peeters PH, May AM, Bueno-de-Mesquita HB, van Duijnhoven FJ, Hallmans G, Weinehall L, Manjer J, Hedblad B, Lund E, Agudo A, Arriola L, Barricarte A, Navarro C, Martinez C, Quirós JR, Key T, Bingham S, Khaw KT, Boffetta P, Jenab M, Ferrari P, Riboli E. General and abdominal adiposity and risk of death in Europe. N Engl J Med 2008; 358: 21052120. [PMID:19005195 doi:10.1056/NEJMoa0801891]

[47] Lavie CJ, Milani RV, Ventura HO. Obesity and cardiovascular disease. Risk factor, paradox, and impact of weight loss. J Am Coll Cardiol 2009; 53: 1925-1932. [PMID:19460605 doi:10.1016/j.jacc.2008.12.068]

[48] Rhoads GG, Kagan A. The relation of coronary disease, stroke and mortality to weight in youth and middle age. Lancet1983;1:492-495. [PMID:6131209 doi:S0140-6736(83)92189-X] 
[49] Allison DB, Faith MS, Heo M, Kotler DP. Hypothesis concerning the U-shaped relation between body mass index and mortality. Am J Epidemiol 1997; 146: 339-349. [PMID:9270413]

[50] Kerhaw EE, Flier JS. Adipose tissue as an endocrine organ. J Clin Endocrinol Metab 2004; 89: 2548-2556. [PMID:15181022 doi:10.1210/jc.2004-0395]

[51] Mohamed-Ali V, Goodrick S, Bulmer K, Holly JM, Yudkin JS, Coppack SW. Production of soluble tumor necrosis factor receptors by human subcutanoeus adipose tissue in vivo. Am J Physiol 1999; 277: E971-E975. [PMID:10600783]

[52] De Pergola G, Pannacciulli N. Coagulation and fibrinolysis abnormalities in obesity. J Endocrinol Invest 2002; 25: 899-904. [PMID:12508953 doi:10.1007/BF03344054] 
